$\begin{array}{llllllll}\mathbf{K} & \mathbf{R} & \mathbf{O} & \mathbf{N} & \mathbf{I} & \mathbf{K} & \mathbf{A}\end{array}$

STUDIA POLONIJNE

T. 39. LUBLIN 2018

DOI: http://dx.doi.org/10.18290/sp.2018.17

SŁAWOMIR ZYCH

\title{
DZIALALNOŚĆ NAUKOWA OŚRODKA BADAŃ NAD POLONIĄ I DUSZPASTERSTWEM POLONIJNYM KUL ZA ROK 2017
}

\section{OBSADA PERSONALNA}

Ośrodek funkcjonował w następującym składzie: dr hab. Jacek Gołębiowski, prof. KUL, oraz adiunkci: dr Paweł Sieradzki (od $1 \mathrm{X}$ - asystent), dr Witalij Rosowski (oddelegowany do administracji uczelnianej) oraz ks. dr Sławomir Zych. Współpracę z Ośrodkiem podejmowała mgr Maria Anna Furtak, doktorantka Instytutu Historii KUL. Dokonano zmian w składzie redakcji „Studiów Polonijnych”: prof. Jacek Gołębiowski i dr Paweł Sieradzki zostali włączeni w skład Rady Naukowej, natomiast funkcję redaktora naczelnego pełni ks. dr Sławomir Zych (od 13 X), a sekretarza - dr Bartosz Walicki, współpracownik Ośrodka.

\section{POLONIJNA NAGRODA NAUKOWA \\ IM. IRENY I FRANCISZKA SKOWYRÓW}

22 stycznia Irena Grocholewska, prezes Zrzeszenia Nauczycielstwa Polskiego za Granicą w Wielkiej Brytanii (ZNPZ), odebrała Nagrodę Naukową im. Ireny i Franciszka Skowyrów z rąk dyrektora Ośrodka Badań nad Polonią i Duszpasterstwem Polonijnym dra hab. Jacka Gołębiowskiego, prof. KUL ${ }^{1}$. Uroczyste wręczenie wyróżnienia odbyło się w Polskim Ośrodku Społeczno-Kulturalnym w Londynie podczas spotkania opłatkowego zorganizowanego przez Zrzeszenie. W spotkaniu wzięli udział: konsul generalny RP Krzysztof Grzelczyk (odczytał list od ministra Adama Kwiatkowskiego, szefa gabinetu prezydenta RP), przedstawiciel Polskiej Misji Katolickiej z parafii św. Andrzeja Boboli w Londynie ks. Janusz Zbroniec, prezes Fundacji Jana Pawła II w Wielkiej Brytanii Ewa

Ks. dr SŁawomir Zych - Ośrodek Badań nad Polonią i Duszpasterstwem Polonijnym KUL; e-mail: szych@kul.pl

${ }^{1}$ Zob. M. Bugaj Martynowska, Laureatka Lubelskiego „,Nobla” wśród nas, „Nowy Czas” 226 (2017), s. 9; J. GolĘBiowski, Polska na Wyspach Brytyjskich, „Przegląd Uniwersytecki” 2 (2017), s. 6. 
Szymańska, a także dyrektorzy i nauczyciele londyńskich szkół sobotnich oraz uczniowie z rodzicami ze szkoły polskiej na Wembley, którzy przygotowali tradycyjne jasełka. Irena Grocholewska w 1956 roku dotarła do Londynu, by po kilkunastoletniej rozłące spowodowanej II wojną światową i komunistycznym zniewoleniem spotkać się z rodzicami. Od lat 60. XX wieku aktywnie działa w takich organizacjach polonijnych w Wielkiej Brytanii, jak Zrzeszenie Nauczycielstwa Polskiego za Granicą (członek zarządu i prezes) oraz Ministerstwo Oświaty i Wyznań Religijnych Rządu RP na Uchodźstwie (sekretarz Wydziału Oświaty). Była członkiem redakcji „Wiadomości Nauczycielskich”, a także sekretarzem Rady Zjednoczenia Polskiego w Wielkiej Brytanii (1978-1990) oraz Skarbu Narodowego na Wielką Brytanię (1985-1991). Aktywnie działała na rzecz obrony dobrego imienia narodu polskiego w mediach anglojęzycznych jako członek Anglo-Polish Conservative Society i Conservative Association Chiswick Branch. Za zasługi w pracy niepodległościowej, szkolno-oświatowej, społecznej i na rzecz Skarbu Narodowego została odznaczona przez prezydentów RP na uchodźstwie Srebrnym i Złotym Krzyżem Zasługi, Złotym Medalem Skarbu Narodowego oraz Krzyżem Kawalerskim Polonia Restituta.

\section{PROJEKTY BADAWCZE}

W terminie 1 czerwca - 31 grudnia Towarzystwo Naukowe KUL realizowało projekt badawczy (grant) ,Zabezpieczenie, opracowanie i digitalizacja źródeł archiwalnych Związku Nauczycielstwa Polskiego za Granicą w 75. rocznicę istnienia", przyznany przez Senat Rzeczypospolitej Polskiej. Kierownikiem projektu był dr hab. Jacek Gołębiowski, prof. KUL ${ }^{2}$.

W lipcu 8-osobowy zespół naukowców z KUL, UKSW, a także historyków i socjologów z USA kierowany przez dra hab. Jacka Gołębiowskiego, prof. KUL, z udziałem dra Pawła Sieradzkiego, rozpoczął pierwszy etap badań w ramach projektu „Parafie i kościoły polskie w USA", sfinansowanego ze środków Ministra Kultury i Dziedzictwa Narodowego w ramach zadania „Ochrona dziedzictwa kulturowego za granicą 2017”3. Beneficjentem przyznanych środków jest Towarzystwo Przyjaciół KUL, a głównym wykonawcą Ośrodek Badań nad Polonią i Duszpasterstwem Polonijnym KUL. W pierwszym etapie badań naukowcy przeprowadzili szczegółową inwentaryzację fotograficzną i źródłową 22 parafii z kategorii polish cathedrals style zlokalizowanych na terenie metropolii Chicago.

1 grudnia na Katolickim Uniwersytecie Lubelskim Jana Pawła II w Lublinie i 8 grudnia na Uniwersytecie Kardynała Stefana Wyszyńskiego w Warszawie odbyły się konferencje naukowe, podczas których zostały zaprezentowane wyniki pierwszego etapu projektu „Parafie i kościoły polskie w USA”, mającego na celu dokumentację polskiego

\footnotetext{
${ }^{2}$ Działalność naukowa Towarzystwa Naukowego KUL, „Summarium” 46 (2017), s. 216.

${ }^{3}$ Zob. K. Cygielska, M. BŁaszczuk, Polskie katedry w Ameryce. Projekt Badawczy KUL i UKSW, „Dziennik Związkowy” 11-13 sierpnia (August 11-13) 2017, s. 11; J. GolĘBIOwski, Polish cathedrals w metropolii Chicago, „Przegląd Uniwersytecki” 1 (2018), s. 26-27; J. JARosińsKA, Ocalić od zapomnienia, „Lubelski Gość Niedzielny” 17 (2017), s. VI; A. KarLIC, „Polish Cathedrals” $w$ Stanach Zjednoczonych przedmiotem badań naukowców z KUL. Nawiąanie wspótpracy z Polska Misja, „The Polish Weekly” z 23-30 VIII 2017, s. 12-13.
} 
dziedzictwa narodowego w Stanach Zjednoczonych ${ }^{4}$. Towarzyszyła im wystawa fotografii obrazujących piękno ,polskich katedr”, autorstwa Norberta Piwowarczyka. Dzięki inwentaryzacji fotograficznej uzyskano kilka tysięcy fotografii ilustrujących architekturę i wystrój obiektów sakralnych, szkół i cmentarzy. Efekty badań są na bieżąco wprowadzane na stronę internetową poświęconą polskim parafiom i kościołom w Stanach Zjednoczonych (kosciolypolskiewusa.com).

\section{KWERENDY ARCHIWALNE I DIGITALIZACJA MATERIAŁÓW}

Dr Paweł Sieradzki prowadził kwerendy i digitalizację materiałów archiwalnych w Polskiej Misji Katolickiej w Lozannie, w Domu Prowincjalnym Zgromadzenia Sióstr Służebniczek NMP w Krakowie, w Archiwum Zrzeszenia Nauczycielstwa Polskiego za Granicą w Londynie, w Centralnym Archiwum Polonii w Orchard Lake oraz archiwach parafialnych polskich kościołów w Chicago.

\section{DZIAŁALNOŚĆ EDUKACYJNA I NAUKOWA WŚRÓD POLONII}

Podobnie jak w latach ubiegłych, prof. Jacek Gołębiowski i dr Paweł Sieradzki wygłaszali prelekcje i referaty na konferencjach organizowanych przez Polską Misję Katolicką w Anglii i Walii (Dublin), Zrzeszenie Nauczycielstwa Polskiego za Granicą (Londyn). Prowadzili także zajęcia $\mathrm{z}$ historii Polski dla uczniów i nauczycieli Szkół Przedmiotów Ojczystych w Londynie, Accrington i Londonderry.

\section{PUBLIKACJE}

„Studia Polonijne” 38(2017), ss. $210+4$ nlb.

„Rocznik Kolbuszowski” 17(2017), ss. $538+2$ nlb. (Redaktorem naczelnym czasopisma jest pracownik Ośrodka ks. dr Sławomir Zych).

Jacek GoŁĘBIOwski, Zrzeszenie Nauczycielstwa Polskiego za Granica 1991-2016, Towarzystwo Naukowe KUL (Źródła i monografie nr 454), Lublin 2017, ss. $195+67$.

Mateusz Szast, W Irlandii wygodniej, ale w Polsce lepiej. Kapitat społeczno-kulturowy $i$ ocena sytuacji życiowej polskich migrantów w Irlandii, Miejska i Powiatowa Biblioteka Publiczna w Kolbuszowej, Ośrodek Badań nad Polonią i Duszpasterstwem Polonijnym KUL, (Biblioteka Polonii, Seria A: Studia, 39), Kraków 2017, ss. $413+3$ nlb.

Rodzina i świat cały. Wspomnienia rodziny Kołodziejskich, Rudzińskich i powinowatych, [zebrała, opracowała i zredagowała Anna KoŁodzIEJSKA], wyd. II, Miejska i Powiatowa Biblioteka Publiczna w Kolbuszowej, Ośrodek Badań nad Polonią i Duszpasterstwem Polonijnym KUL, Kolbuszowa 2017, ss. 266 (il.).

\footnotetext{
${ }^{4}$ J. GolĘBIowski, Polish cathedrals w metropolii Chicago, „Przegląd Uniwersytecki” 1 (2018), s. $26-27$.
} 
Ponadto pracownicy Ośrodka opublikowali kilka artykułów w czasopismach naukowych, a ks. dr Sławomir Zych był współredaktorem książki Huta Polańska dawniej i dziś. Studia i materiały, red. ks. Jan Delekta, ks. Krzysztof Szopa, ks. Sławomir Zych, Rzeszów 2017 (ss. $235+14$ nlb.). Opracował on również dzieje poszczególnych parafii diecezji rzeszowskiej (zob. Schematyzm jubileuszowy diecezji rzeszowskiej. Stan z dnia 1.12.2016 r., red. ks. Jerzy Buczek, Rzeszów 2017, ss. 1224). 